\title{
Metabolism of dimethylsulfoniopropionate (DMSP) by juvenile Atlantic menhaden Brevoortia tyrannus
}

\author{
Richard W. Hill ${ }^{1, *}$, John W. H. Dacey ${ }^{2}$ \\ ${ }^{1}$ Department of Zoology, 203 Natural Science Building, Michigan State University, East Lansing, Michigan 48824, USA \\ ${ }^{2}$ Department of Biology, Woods Hole Oceanographic Institution, Woods Hole, Massachusetts 02543, USA
}

\begin{abstract}
Dimethylsulfoniopropionate (DMSP) synthesized by marine phytoplankton is the principal source of dimethylsulfide (DMS), an important climate-affecting gas. Prior research has demonstrated that grazing by invertebrate phytoplanktivores often affects the dynamics of DMS production from algal DMSP, but the effects of grazing by phytoplanktivorous fish have not previously been investigated. We studied the fate of algal DMSP following grazing by juvenile Atlantic menhaden Brevoortia tyrannus (13 cm fork length), which are generally viewed as the most specialized for phytoplanktivory of all postlarval fish. The menhaden were fed the dinoflagellate Prorocentrum micans, containing 1 to 2 pmol DMSP cell ${ }^{-1}$. During the first $24 \mathrm{~h}$ following ingestion of algal DMSP, almost none of the DMSP (ca. 1\%) appeared as DMS. About $21 \%$ of ingested DMSP appeared in the water column as dissolved DMSP, peaking in concentration 9 to $11 \mathrm{~h}$ after feeding; in natural settings, this fraction would be poised for microbial metabolism, including potential conversion to DMS in surface waters from which outgassing to the atmosphere could occur. About $10 \%$ of ingested DMSP appeared in fecal pellets that tended to sink rapidly toward the bottom of the tanks. About $33 \%$ of ingested DMSP was deposited in the tissues of the menhaden, in particular in the red and white swimming muscles, in which we observed concentrations exceeding $0.7 \mu \mathrm{mol} \mathrm{g}{ }^{-1}$. This final fraction could ultimately be metabolized to DMS, or it could be passed up food chains and possibly act as a taste factor in commercially important piscivores such as striped bass and bluefish. In total, our research demonstrated that at least two-thirds of the ingested DMSP ends up in tissues or feces or in solution in the ambient water in the first $24 \mathrm{~h}$ after feeding, and virtually none is converted to ambient DMS during that time period.
\end{abstract}

KEY WORDS: Dimethylsulfide $\cdot$ Dimethylsulfoniopropionate $\cdot$ Menhaden $\cdot$ DMS $\cdot$ DMSP $\cdot$ Brevoortia tyrannus $\cdot$ Taste factor $\cdot$ Phytoplanktivory

Resale or republication not permitted without written consent of the publisher

\section{INTRODUCTION}

Dimethylsulfoniopropionate (DMSP) synthesized by marine algae is the root source of over half the nonanthropogenic gaseous sulfur flux to the atmosphere (Andreae 1990, Bates et al. 1992). Atmospheric sulfur flux is of interest because sulfur gases are believed to play major roles in global climate. DMSP itself is not volatile. One of its breakdown products, however, is dimethylsulfide (DMS), a water-soluble gas, which, when produced in the surface waters of oceans, can outgas to the atmosphere. Atmospheric DMS is oxidized to aerosol particulates, including cloud condensation nuclei that affect oceanic cloud cover and thus the Earth's reflectivity (albedo) to incoming solar radiation (Charlson et al. 1987, Andreae \& Crutzen 1997 Malin \& Kirst 1997).

The conversion of algal DMSP to DMS is mediated by biological processes, including microbial DMSP metabolism (Yoch 2002), viral lysis of phytoplankton cells (Hill et al. 1998), senescence of cells, and grazing by animals. Dacey \& Wakeham (1986) first introduced the concept that animal grazing on phytoplankton affects the dynamics of DMS production from algal DMSP by demonstrating that feeding by copepods (Labidocera aestiva and Centropages hamatus) on dinoflagellates [Gymnodinium sanguineum (= nelsonii) and Prorocentrum micans] in laboratory cultures 
accelerated by over 20-fold the formation of DMS from algal DMSP. Subsequent investigations of grazing effects on DMS formation from DMSP have employed laboratory systems to study other predator-prey relations or have sought evidence in natural waters, such as correlative evidence between DMS concentrations and grazer densities. Results have been mixed (e.g. Lee et al. 2003). For example, whereas a number of laboratory studies on crustacean plankton have confirmed the finding of Dacey \& Wakeham (1986) that the rate of DMS formation is increased by grazing (Daly \& DiTullio 1996, Lee et al. 2003, Kasamatsu et al. 2004), Kwint et al. (1996) found no effect. Notwithstanding variability, at present a substantial body of evidence exists that zooplankton grazing can exert major effects on the rate of DMS production, tending to increase the DMS concentration in sea surface waters and thereby force a greater flux of DMS to the atmosphere. The zooplankton implicated include copepods (Dacey \& Wakeham 1986, Lee et al. 2003), krill (Daly \& DiTullio 1996, Kasamatsu et al. 2004), and microzooplankton (Archer et al. 2003), although Kasamatsu et al. (2004) reported, based on short incubations, that salp grazing does not affect DMS production. No prior study has examined the effects of grazing by vertebrates, including phytoplanktivorous fish.

We report here on the processing of algal DMSP by juvenile Atlantic menhaden Brevoortia tyrannus. Menhaden (Ahrenholz 1991) are an obvious choice for the study of DMSP processing by fish for 2 reasons: their exceptional adaptations for phytoplanktivory and their large populations. Among postlarval fish, juvenile and adult menhaden possess the most elaborate mechanism known for feeding on phytoplankton. Their gill rakers are exceptionally numerous and long, and are lined on both sides with secondary projections that impart a pinnately divided overall form (June \& Carlson 1971, Friedland 1985). The rakers form an elaborate sieving apparatus (Friedland 1985) that the fish employs to remove phytoplankton and other small plankton or suspended material from the water. The size range of phytoplankton that menhaden can filter evidently depends on the size of the fish. Juveniles with an average fork length of $14 \mathrm{~cm}$ were observed to filter cells as small as 7 to $9 \mu \mathrm{m}$ (Friedland et al. 1984), whereas adults of $26 \mathrm{~cm}$ average fork length filtered cells as small as 13 to $16 \mu \mathrm{m}$ (Durbin \& Durbin 1975). Detritus in the water permits juveniles to filter phytoplankton even smaller than those just specified (Friedland et al. 1984), possibly by tending to clog openings in the filtering apparatus, reducing the dimensions of the openings. The size range of phytoplankton that can be harvested by menhaden is broad enough to include a great diversity of DMSP-synthesizing species (Keller et al. 1989). Thus, in the mixed phytoplankton that often dominates the diet of menhaden (June \& Carlson 1971, Durbin \& Durbin 1975, Friedland et al. 1984, Ahrenholz 1991), DMSP must frequently be a significant component.

Large populations of menhaden are found in coastal and estuarine waters. This is especially true if one considers both Atlantic menhaden and the closely related Gulf menhaden Brevoortia patronus. Landings of the 2 species in a given year have often accounted for 30 to $40 \%$ of the biomass of all commercial fish landings in waters of the contiguous United States (Vaughan 1991). Numbers caught by US fleets often exceed $1 \times$ $10^{10} \mathrm{yr}^{-1}$ (Smith 1991). The numbers of individuals aged $1 \mathrm{yr}$ or older in natural populations in US waters have been estimated in many years to be 3 to $4 \times 10^{10}$ (Vaughan \& Merriner 1991). The sheer numbers of menhaden suggest that processing of DMSP by these fish is likely to be important in sulfur biogeochemistry within the coastal and estuarine regions they inhabit.

In addition to its potential biogeochemical significance, the processing of DMSP by menhaden is also of interest because these fish might act as vectors of negative taste factors into other fish species. DMSP itself has little, if any, taste or odor. DMS, however, has a potent taste and odor, which are offensive at high micromolar concentrations. When DMSP that has passed up food chains accumulates in the tissues of fish used as human food, postmortem breakdown to DMS can impart repellent tastes and odors to the fish (Ackman et al. 1966, Levasseur et al. 1994), even to the extent of sometimes forcing large quantities of fish or fish products to be discarded. Menhaden are a principal forage species for commercially important piscivores such as bluefish Pomatomus saltatrix, striped bass Morone saxatilis, and bonito Sarda sarda (Ahrenholz 1991, Walter \& Austin 2003). If menhaden that are feeding on DMSP-rich phytoplankton accumulate DMSP in their tissues, they might pass significant burdens to table fish that feed on them.

We performed a series of studies on juvenile Atlantic menhaden to elucidate their processing of the DMSP acquired from feeding on Prorocentrum micans, a preferred food (Friedland et al. 1989). We found that menhaden direct algal DMSP into multiple paths: they accumulate some, release some to the dissolved DMSP pool, and send some toward the bottom in feces.

\section{MATERIALS AND METHODS}

Young Atlantic menhaden Brevoortia tyrannus were captured offshore from Woods Hole, Massachusetts, USA, in autumn and were held in an outdoor impoundment with tidal exchange, where they continued to feed on ambient food. The set of 65 fish used in exper- 
iments was moved to indoor tanks at the National Marine Fisheries Service laboratory in Woods Hole in early November, about 1 mo before experiments were started. Experiments lasted 1 mo.

Fish were housed indoors in 2 cylindrical Kalwall tanks (110 cm diameter, $91 \mathrm{~cm}$ high) covered with netting. The water in the tanks was aerated using bubbling stones and renewed continuously from a highvolume filtration-recirculation system. An overflow port $78 \mathrm{~cm}$ from the bottom kept the water volume in each tank at $740 \mathrm{l}$. Inflow maintained the water in circular motion, and the fish often swam as a school against the current. Salinity was 31 to 33 ppt. Temperature was 15 to $16^{\circ} \mathrm{C}$. Lights were on between 05:00 and 17:00 h Eastern Standard Time. Tank bottoms were vacuumed at least once per day.

We performed 4 studies on the fish; 2 focused on the exchanges of DMSP and DMS between the animals and the ambient water; 1 focused on the deposition of DMSP in the tissues of the fish; and 1 focused on the elimination of DMSP in feces. All the studies were performed in the same tanks that were used to house the fish, but with the water renewal system turned off. Water depth during studies was set initially to $50 \mathrm{~cm}$, giving a volume of $480 \mathrm{l}$. Subsequent addition of algal culture increased the volume to 5301 in each study. During 2 studies that were particularly long, a partial water change was carried out at a time compatible with experimental objectives. Black curtains surrounded each tank during each study to minimize visual disturbance. The studies on DMSP/DMS exchange between the fish and ambient water required a fully closed system. To achieve this, the top of the tank was covered with a sheet of acrylic plastic (Plexiglas), and the seam between the top and walls was sealed using Fisherbrand label tape. Aeration of the water in the closed tank was achieved with an external peristaltic pump (Masterflex 7570-10) that drew gas from the tank headspace and delivered it to a submerged bubbling stone via a single length of Tygon tubing (6 $\mathrm{mm}$ diameter) that passed through 2 ports in the plastic sheet sealing the top. Two other ports through the top (plugged with glass stoppers when not in use) permitted withdrawal of water samples (via a $3 \mathrm{~mm}$ diameter Teflon tube opening at mid-depth) and addition of food.

The capacity of the sealed tanks to retain DMS was assessed in 2 preliminary tests. A sealed tank with the aeration system operating as in experiments, but containing no fish, was filled to the $50 \mathrm{~cm}$ level with seawater from the filtration-recirculation system and injected with pure DMS (Fluka) to bring the water concentration to approximately $100 \mathrm{nM}$. The DMS level remained equal to the initial concentration for $4 \mathrm{~h}$ and fell to no lower than $95 \%$ of the initial concentration after $20 \mathrm{~h}$, demonstrating that there was little DMS leakage from the tank and little destruction by microbes in the water used.

Food for routine maintenance was Purina 5106 fish chow, ground to a fine powder and mixed with water to form a slurry. Fish were provided daily with 1.1 to $1.6 \mathrm{~g}$ dry weight animal ${ }^{-1}$. Analysis showed that the chow was essentially free of DMSP and DMS $\left(<2 \mu \mathrm{mol} \mathrm{kg}{ }^{-1}\right.$ dry weight).

Food for experiments was the dinoflagellate Prorocentrum micans. Our culture, which had been maintained for many generations at the Woods Hole Oceanographic Institution, was descended from CCMP689 (Provasoli-Guillard Center for Culture of Marine Phytoplankton). Average cell dimension was $37 \times 20 \mu \mathrm{m}$. The algae were grown in ca. 171 lots in glass carboys in autoclaved $\mathrm{f} / 2$ medium at $20^{\circ} \mathrm{C}$, with steady illumination from banks of fluorescent bulbs and bubbling with sterile air. Cultures were grown to a density of 2 to $4 \times 10^{4}$ cells $\mathrm{ml}^{-1}$. Average DMSP content at the point of use was 0.8 to $1.7 \mathrm{pmol} \mathrm{cell}^{-1}$. A total volume of about $50 \mathrm{l}$ of culture was used in each study.

Exchange of DMSP and DMS between the fish and ambient water. A school of 28 menhaden each weighing between 24 and $42 \mathrm{~g}$ (mean: $33.3 \mathrm{~g}$ ) was studied on 2 occasions, $12 \mathrm{~d}$ apart, in a fully sealed tank to ascertain the exchanges of DMS, dissolved DMSP (DMSPd), and particulate DMSP (DMSPp) between the fish and their ambient water. At the start of each study, cell density in each of 3 carboys of Prorocentrum micans was counted by hemacytometer. The carboys were then siphoned into the tank over a period of 4 to $8 \mathrm{~min}$. Samples of tank water were drawn using a gas-tight syringe, both before and ca. $10 \mathrm{~min}$ after addition of the culture. Assays of these samples for DMSPp were used to calculate the total ingestible DMSP added and the DMSP per algal cell. A small ration of the trout chow maintenance diet was added to the tank water, either along with the addition of $P$. micans, or shortly thereafter, to help stimulate feeding.

Following the addition of Prorocentrum micans, water samples were removed from the tank periodically for $22 \mathrm{~h}$ (first trial) or $15 \mathrm{~h}$ (second trial). Duplicate samples (each $30 \mathrm{ml}$ ) were removed at each sampling time and analyzed independently. Oxygen was added by periodic injections to the tank headspace at an average rate of 1 to $1.5 \mathrm{l} \mathrm{h}^{-1}$, calculated (based on the routine metabolic rate of similar-size individuals [Hettler 1976] and the factorial increase caused by feeding [Hettler 1976, Durbin et al. 1981]) to replace the $\mathrm{O}_{2}$ used by the fish.

For assay of DMSPp in a water sample, the sample was drawn under slight vacuum through a Gelman A/E glass fiber filter supported in a Nucleopore SwinLok filter holder (first trial) or supported on the fritted 
glass platform of a glass filter holder (second trial and all other studies; we changed the support because filters were occasionally torn in the Swin-Lok holder). The filter was placed in $25 \mathrm{ml}$ of $1 \mathrm{~N}$ potassium hydroxide $(\mathrm{KOH})$ in a glass vial sealed with a Teflon-coated butyl rubber septum (Regis). Incubation in base converts DMSP to DMS (Dacey \& Blough 1987). After sufficient time had passed for DMSPp to be fully converted to DMS, the DMS was measured by sulfurspecific gas chromatography employing a Chromosil 330 (Supelco) column and Sievers 350A sulfur chemiluminescence detector. During the first trial, diluted liquid from each sample vial was processed for assay by sparging and cryotrapping (see next paragraph). During the second trial and all other studies, headspace gas was analyzed.

For assay of DMS and DMSPd in a water sample, the filtrate from the filtration step was collected directly from the filtering apparatus into a sealed glass vial. Ambient DMS was measured in all studies by sparging a subsample of the filtrate with DMS-free carrier gas, cryotrapping removed DMS on cold Tenax-GC (Alltech), and then heating the Tenax to thermally desorb the DMS for measurement by sulfur-specific gas chromatography, as already described. DMSPd was measured by alkalinizing ( 1 or $2 \mathrm{~N} \mathrm{KOH}$ ) a subsample of the filtrate in a sealed glass vial to convert DMSPd to DMS, then measuring DMS by sparging/cryotrapping or headspace analysis, and subtracting native DMS. Alternatively, DMSPd was measured by bubbling a subsample of filtrate with air for $20 \mathrm{~min}$ to remove native DMS, then alkalinizing and analyzing the filtrate.

For all assays, standards were prepared using reagent DMS (Fluka) in background solutions that matched unknowns.

Tissue deposition. Deposition of ingested DMSP in the body tissues of menhaden was measured on a school of 25 fish each weighing between 20 and $52 \mathrm{~g}$ (mean: $40.2 \mathrm{~g}$ ). These fish were derived from a larger group that had eaten only the trout chow maintenance diet since the time fish were moved into the indoor tanks about 2 mo before the study. The school of 25 fish was fed Prorocentrum micans in the standardized manner already described. Water samples were taken periodically for $13 \mathrm{~h}$ to track consumption of the algae. The samples were analyzed for DMSPp and DMSPd as previously described; however, because the top of the study tank was not sealed, DMS may have escaped and therefore was not monitored. Six fish were sacrificed at 13 to $16 \mathrm{~h}$ after feeding. Four additional fish that were from the same larger group of fish, but that had been kept for $2 \mathrm{wk}$ in a separate tank and fed only the trout chow maintenance diet, were sacrificed at the same time. Weighed samples of red and white swim- ming muscle, liver, brain, and visceral fat were taken from each fish sacrificed. The gastrointestinal (GI) tract was discarded (we kept as much of the visceral fat as practical with the carcass at this step, but fat adhering closely to the GI tract was not meticulously removed prior to discarding). The remainder of each carcass (i.e. the carcass minus the tissue samples and GI tract) was pureed in $200 \mathrm{ml}$ of water. The samples of specific tissues and $2 \mathrm{ml}$ of the carcass homogenate were each placed in $25 \mathrm{ml}$ of $1 \mathrm{~N} \mathrm{KOH}$ in a sealed glass vial. After sufficient time had passed for DMSP in tissue samples to be converted to DMS, headspace samples from the vials were assayed for DMS.

To check that the presence of tissue material did not affect standardization of gas chromatographic data, we compared standards made with reagent DMS in $25 \mathrm{ml}$ of $1 \mathrm{~N} \mathrm{KOH}$ with ones made in $23 \mathrm{ml}$ of $1 \mathrm{~N} \mathrm{KOH}$ plus $2 \mathrm{ml}$ of homogenate from control fish, which proved to contain almost no DMSP or DMS. There were no consistent differences between the 2 series of standards.

Fecal excretion. The excretion of ingested DMSP in feces was estimated on the same school of fish used for the tissue deposition study. Fecal excretion was measured $2 \mathrm{~d}$ after the tissue deposition study, when the school consisted of 19 fish ( 6 having been sacrificed earlier). Both 3 and $0.6 \mathrm{~h}$ prior to feeding, the bottom of the open-topped tank was thoroughly vacuumed by siphon. Then the school was fed Prorocentrum micans in the standardized manner. Feces were collected periodically over a period of $22 \mathrm{~h}$ thereafter, by thorough siphoning of the bottom. Duplicate water samples were taken periodically, including just prior to each fecal collection, via the water-sampling tube, and were analyzed for DMSPp.

During collection of feces, the amount of water removed along with the feces was minimized by maintaining a small difference between siphon inlet and outlet heights; thorough cleaning of the tank bottom could be achieved with removal of $<81$ of water, which was delivered to an 81 white bucket. Calculations convinced us of the importance of minimizing contamination of the feces by uneaten Prorocentrum micans in the water, because relatively small quantities of algal cells could distort fecal measures. To dilute algal cells, feces in the bucket were allowed to settle for 10 to 20 min after collection; then the supernatant (all but $550 \mathrm{ml}$ of the total volume) was removed by decanting and siphoning, and the bucket was refilled with DMSP-free water. Decanting and refilling were usually repeated, at which point any suspended algal cells in the original sample were diluted by a factor of about 150. All feces in the bucket were then siphoned into a $1 \mathrm{l}$ flask, typically accompanied by $850 \mathrm{ml}$ of bucket water. The flask was shaken violently, and an approxi- 
mately $100 \mathrm{ml}$ sample was poured out immediately for assay. A second sample was taken in the same way. The samples, in sealed vials, were alkalinized by addition of concentrated sodium hydroxide $(\mathrm{NaOH})$ to bring the concentration to $1 \mathrm{~N}$ and incubated until fecal DMSP was converted to DMS, which was analyzed by use of headspace gas. Besides the samples already described, 2 additional samples were transferred to sealed vials and not alkalinized to determine what fraction of fecal DMSP would be converted to DMS by natural processes.

Two procedural checks were carried out. The first concerned artifacts that might have arisen during sampling of fecal suspensions. Although we poured off samples immediately following violent shaking, some fecal components settled so rapidly that samples might not have been representative of the material from which they were withdrawn. To test for such problems, in 3 cases we alkalinized and analyzed the entire volume of fecal suspension that remained after sample removal. In all cases, we found no difference in DMS concentration between the alkalinized samples and residual suspension, demonstrating that samples were representative. Our second procedural concern was whether the presence of fecal matter in samples, but not standards, might affect calibration of our DMS measures. To assess this concern, we collected lowDMSP feces from fish that had been eating only the trout chow maintenance diet for 1 mo and prepared $25 \mathrm{ml}$ standards (using reagent DMS) with and without $0.1 \mathrm{~g}$ (dry weight) of this feces. The measured DMS concentrations of standards containing feces differed from the concentrations of matched feces-free standards only to the extent predicted from the measured DMSP content of the feces.

\section{RESULTS}

Simultaneous measurements of fork length and body weight of Atlantic menhaden Brevoortia tyrannus were made on samples of fish that died or were sacrificed about midway through or at the end of experiments. Fig. 1 shows that weight at a given length in our fish resembled that in a set of freshly caught menhaden described in the literature (McHugh et al. 1959), indicating that normal body condition was maintained in our captive fish. Fork lengths of 38 fish were 11.3 to $14.3 \mathrm{~cm}$ (mean: $12.6 \mathrm{~cm}$ ), indicating that they were likely young of the year (McHugh et al. 1959, Nicholson \& Higham 1965).

The menhaden responded to the introduction of food, whether fish chow or Prorocentrum micans, by adopting stereotyped feeding behaviors fitting prior descriptions (Durbin \& Durbin 1975, Friedland et al.

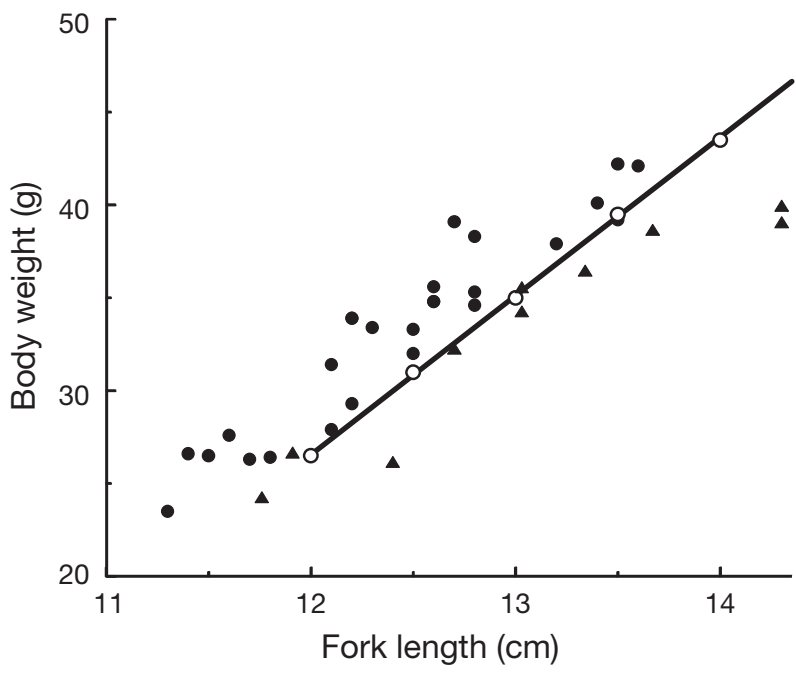

Fig. 1. Brevoortia tyrannus. Body weights and fork lengths in 2 sets of individuals from our study ( $\mathbf{\Lambda}$ : the 10 fish sacrificed in the study of tissue deposition; $\bullet 26$ fish that died accidentally and were measured several hours postmortem). O, 二: regression for freshly caught fish taken from pound nets in the York River, part of the Chesapeake Bay estuary (McHugh et al. 1959, their Table 3, average of seasonal weights)

1984). Swimming as a school, they propelled themselves vigorously forward with mouths in a fixed, open position most of the time.

\section{Exchange of DMSP and DMS between the fish and ambient water}

As seen in Fig. 2, the menhaden rapidly cleared a meal of Prorocentrum micans from the water; $>90 \%$ of the added DMSPp was removed within $3 \mathrm{~h}$. Using $6 \mathrm{~h}$ as a nominal end-point for feeding (Table 1), about $95 \%$ of $P$. micans was ingested in both trials.

Almost no DMS was produced. The DMS concentration of the ambient water (initially 0) rose to only $36 \mathrm{nmol} \mathrm{l}^{-1}$ after $22 \mathrm{~h}$ in the first trial, and $21 \mathrm{nmol} \mathrm{l}^{-1}$ after $15 \mathrm{~h}$ in the second trial; these accumulations of DMS corresponded to 1.6 and $0.4 \%$ of the algal DMSP ingested. By about $5 \mathrm{~h}$ following feeding, the concentration of DMSPd in the ambient water started to rise markedly. The DMSPd concentration peaked 9 to $11 \mathrm{~h}$ after feeding and at that time represented $19 \%$ (first trial; Fig. 2a) or $23 \%$ (second trial; Fig. 2b) of the algal DMSP ingested.

\section{Tissue deposition}

The ingestion of algal DMSP in this study followed a trajectory very similar to that observed earlier (Fig. 2), and, after 6 h, $94 \%$ of the algal DMSP had 
been ingested (Table 1). DMSPd in the ambient water increased markedly after $6 \mathrm{~h}$ and peaked at about $11 \mathrm{~h}$, as before, but, for reasons unknown, its peak concentration represented only about $8 \%$ of the

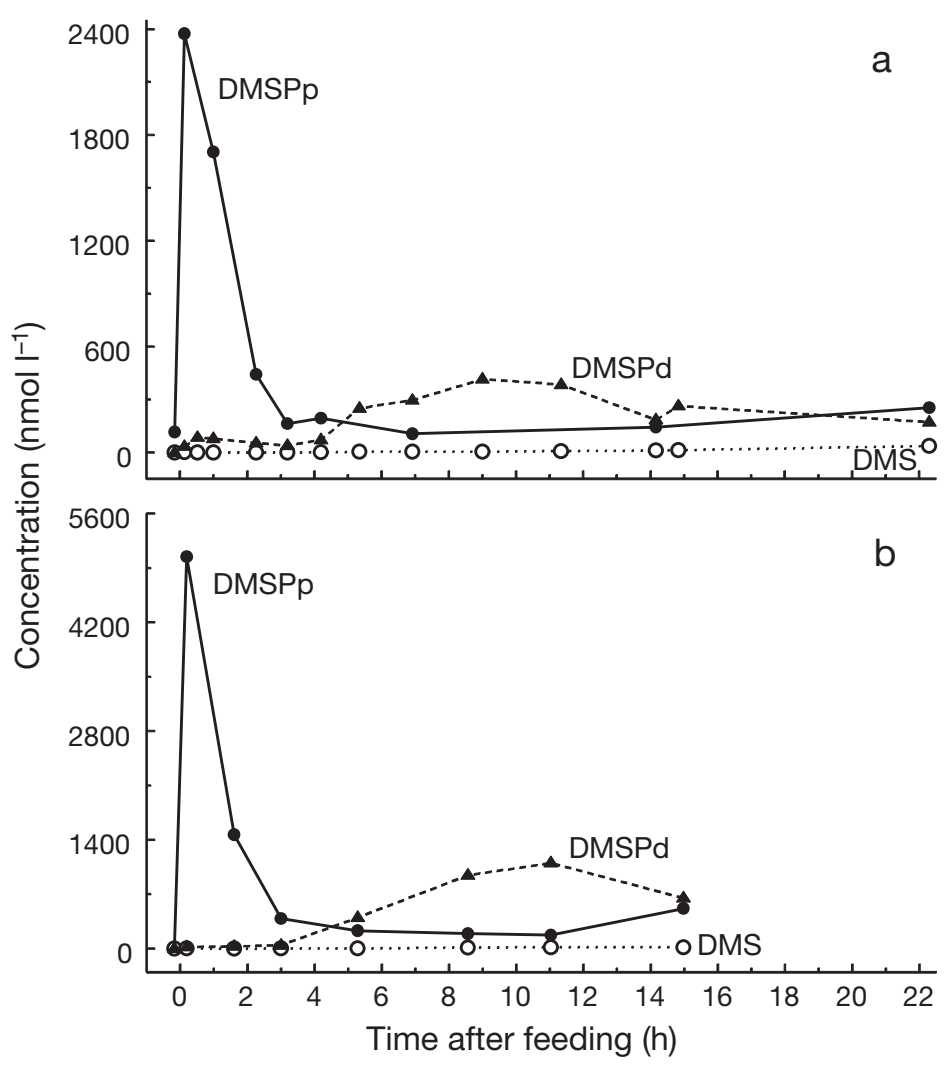

Fig. 2. Concentrations of particulate (DMSPp) and dissolved dimethylsulfoniopropionate (DMSPd) and dimethylsulfide (DMS) in the ambient water, as functions of time after feeding of Brevoortia tyrannus in the first (a) and second (b) trial in our study of the exchange of DMSP and DMS between the fish and ambient water. Time zero (0): point

when the culture of Prorocentrum micans was added to the tank quantity of DMSP the fish ingested in the tissue deposition study.

Although our assay method for tissue samples did not distinguish between DMSP and DMS, we refer here to the material in tissues as DMSP for simplicity of language and, more importantly, because most of the material in tissues was almost certainly DMSP rather than DMS. Investigators who have assayed fish meat to distinguish between DMSP and DMS report that only a small fraction of the total is DMS (e.g. Iida et al. 1986). Moreover, there was no smell of DMS in the menhaden we analyzed; this, in itself, means the concentration of DMS was very low, given that DMS at a concentration of $19 \mathrm{nmol} \mathrm{g}^{-1}$ in an oil background is obvious to the human nose and that considerably lower concentrations are detectable (Brooke et al. 1968).

All tissues had accumulated greatly increased concentrations of DMSP 13 to $16 \mathrm{~h}$ after a single meal of Prorocentrum micans (Table 2). 'Carcass remainder' values in the table were measured on the homogenates. The value for the whole carcass (excluding the gastrointestinal tract) of each fish was calculated by adding together the total DMSP in the carcass remainder and in the 5 specific-tissue samples taken from the fish, then dividing by the total weight of the remainder and tissue samples. The red and white swimming muscles accumulated particularly high concentrations of DMSP. The concentration in the carcass taken as a whole was only about half that in the muscle samples.

We calculated that $33 \%$ of the algal DMSP ingested was deposited in the tissues of the fed menhaden. We weighed all 25 fish in the

Table 1. Food (Prorocentrum micans) provided and ingested in the 4 major studies included in the present research. Algal cell density was calculated from hemacytometer counts on carboy cultures; average number of cells ml ${ }^{-1}$ in the cultures was calculated from the counts, then multiplied by the ratio of total culture volume over total water volume in the tank after the addition of the cultures. DMSP fed to and DMSP ingested by Brevoortia tyrannus were calculated from our direct measurements of DMSPp in the tank water shortly after feeding and $6 \mathrm{~h}$ later (DMSPp per unit volume multiplied by tank water volume); these data are presented at more than 2 significant figures so that differences are not obliterated. Cellular DMSP content was calculated as the ratio of total DMSPp fed over total number of algal cells (tabulated algal cell density $\times$ tank water volume)

\begin{tabular}{|lcccc|}
\hline Study & $\begin{array}{c}\text { Algal cell density } \\
\text { in tank water after } \\
\text { feeding }\left(\text { cells ml }{ }^{-1}\right)\end{array}$ & $\begin{array}{c}\text { Cellular DMSP } \\
\text { content } \\
\left(\text { pmol cell }{ }^{-1}\right)\end{array}$ & $\begin{array}{c}\text { Total DMSP } \\
\text { fed } \\
(\mu \mathrm{mol})\end{array}$ & $\begin{array}{c}\text { DMSP ingested } \\
\text { within } 6 \mathrm{~h} \\
(\mu \mathrm{mol})\end{array}$ \\
\hline $\begin{array}{l}\text { Exchange of DMSP and DMS } \\
\text { with ambient water: }\end{array}$ & & & & \\
First trial & 3100 & 0.77 & 1249 & 1177 \\
Second trial & 3000 & 1.70 & 2654 & 2537 \\
Tissue deposition & 2300 & 0.98 & 1183 & 1114 \\
Fecal excretion & 2100 & 1.40 & 1500 & 1190 \\
\hline
\end{tabular}


Table 2. Brevoortia tyrannus. Concentration of DMSP (mean \pm $\mathrm{SE})$ in tissues of individuals $(\mathrm{n}=6)$ fed a single meal of Prorocentrum micans, measured 13 to $16 \mathrm{~h}$ after feeding, and in control individuals $(n=4)$. Values for the carcass remainder and whole carcass exclude the gastrointestinal tract. The carcass remainder was the carcass minus the samples of muscle and other specific tissues cut out for analysis. Whole carcass values were calculated from the other data. All measures except those of visceral fat in control fish exhibited a normal statistical distribution (Shapiro-Wilk's $W$-test)

\begin{tabular}{|c|c|c|}
\hline \multirow[t]{2}{*}{ Tissue } & \multicolumn{2}{|c|}{$\begin{array}{l}\text { DMSP per unit wet weight } \\
\text { of tissue }\left(\mathrm{nmol} \mathrm{g}^{-1}\right)\end{array}$} \\
\hline & Fed fish & Control fish \\
\hline White muscle & $730 \pm 140$ & $0.95 \pm 0.04$ \\
\hline Red muscle & $820 \pm 150$ & $1.30 \pm 0.14$ \\
\hline Liver & $400 \pm 130$ & $1.10 \pm 0.66$ \\
\hline Brain & $80 \pm 17$ & $0.00 \pm 0.00$ \\
\hline Visceral fat & $170 \pm 33$ & $0.68 \pm 0.68$ \\
\hline Carcass remainder & $420 \pm 66$ & $0.45 \pm 0.28$ \\
\hline Whole carcass & $430 \pm 69$ & $0.48 \pm 0.27$ \\
\hline
\end{tabular}

school, and their collective total body weight was $1004 \mathrm{~g}$. The weight of the body, free of the gastrointestinal tract, averaged $86 \%$ of the total body weight $(n=9$; range: 84 to $88 \%$ ). Thus, the total DMSP accumulated within the tissues of the school of menhaden was estimated to have been $430 \mathrm{nmol} \mathrm{g}^{-1}$ (Table 2) $\times 863 \mathrm{~g}$, or $371 \mu \mathrm{mol}$, which was $33 \%$ of the $1114 \mu \mathrm{mol}$ ingested (Table 1 ).

\section{Fecal excretion}

Algal DMSP was cleared from the water more slowly during the study of fecal excretion than in the 3 previous investigations (Fig. 3), and, after 6 h, only $80 \%$ of the algal DMSP had been ingested (Table 1). The slower feeding was likely a consequence of the fecal sampling procedure, which perceptibly disturbed the fish.

DMSP in feces had risen sharply by $3.4 \mathrm{~h}$ after Prorocentrum micans was provided and peaked at $6.2 \mathrm{~h}$ following feeding (Fig. 3). The DMSP in all fecal collections summed to $122 \mu \mathrm{mol}$, of which $59 \%$ was collected at $6.2 \mathrm{~h}$ and $96 \%$ was collected between 3.4 and $9.4 \mathrm{~h}$. The total collected represented a little over $10 \%$ of the DMSP ingested (Table 1). In the fecal samples collected at $6.2 \mathrm{~h}$ and afterward (though not before), we observed a nonsettling floc, colored orange-brown, in the siphoned water. The floc was removed by our fecal washing procedure.

Fecal samples sealed in vials without alkalinization and stored at $13^{\circ} \mathrm{C}$ exhibited DMS concentrations $92 \%$ as high as those in alkalinized samples when assayed after about $30 \mathrm{~h}$. Thus, natural conversion of fecal DMSP to DMS was almost complete.

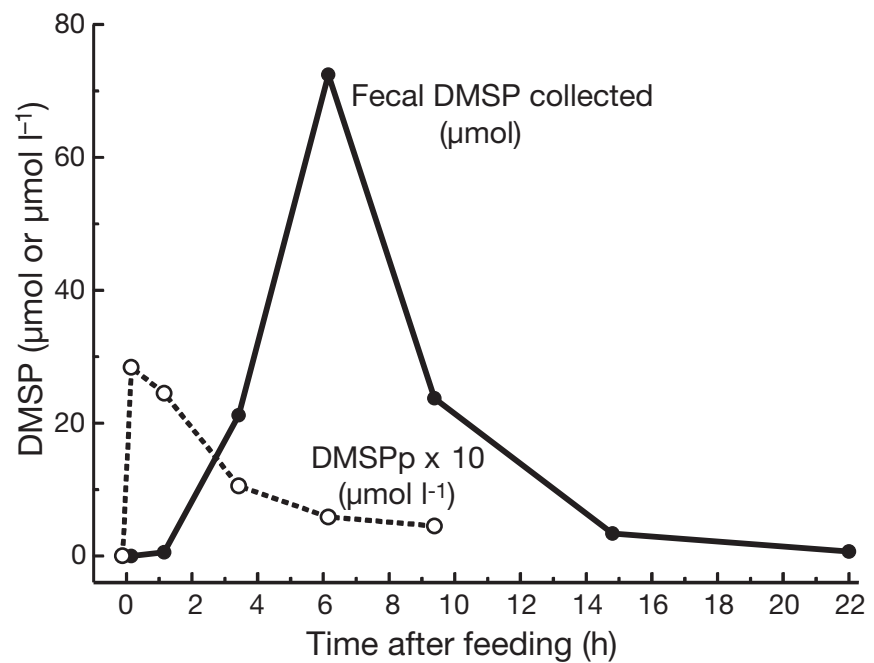

Fig. 3. Fecal DMSP and DMSPp in the water as functions of time after feeding of Brevoortia tyrannus in the fecal excretion study. Whereas fecal DMSP is expressed as total DMSP $(\mu \mathrm{mol})$ in each fecal collection, DMSPp is expressed as a concentration $\left(\mu \mathrm{mol} \mathrm{l^{-1 }}\right)$ in the ambient water; DMSPp concentrations are multiplied by 10 to make the data easier to read

\section{DISCUSSION}

Our most salient result is that phytoplanktivory by menhaden Brevoortia tyrannus does not accelerate the conversion of algal DMSP to ambient DMS during the first $24 \mathrm{~h}$ after feeding (Fig. 2). The near-zero accumulation of DMS indicates there was little DMS production, because we know from our tests with reagent DMS that DMS persisted when added to the water in our tanks. The failure of menhaden phytoplanktivory to accelerate DMS formation is consistent with the sloppy feeding hypothesis for acceleration of DMS production by copepod and krill grazing. As articulated by Kasamatsu et al. (2004) and others, if break-up and incomplete ingestion of phytoplankton cells during feeding are instrumental actions in the prompt acceleration of DMS production by grazing, phytoplanktivores that ingest algal cells whole would not be expected to accelerate DMS production, except possibly in long-delayed ways after feeding. Menhaden ingest cells whole according to what is known of their mode of feeding.

What is the fate of algal DMSP ingested by menhaden over the first $24 \mathrm{~h}$ following feeding? Our results account for about two-thirds of the ingested DMSP: we found that $21 \%$ of the ingested DMSP appears as ambient DMSPd (Fig. 2, average of the 2 trials), $33 \%$ is deposited in the tissues of the fish (Table 2), and $10 \%$ is excreted in negatively buoyant fecal pellets that tend to sink rapidly toward the bottom (Fig. 3). 
Focusing first on the rise in ambient DMSPd (Fig. 2), a point to stress is that in our study DMSPd was defined in practice as the DMSP that passed the glassfiber filters we employed. The timing of the rise in ambient DMSPd rules out sloppy feeding or other ingestion processes as the cause; DMSPd increases distinctly after most of the ingestion process has been completed (Fig. 2). Timing also seems to rule out fecal elimination as the cause of the rise in ambient DMSPd. Whereas excretion of DMSP-containing feces peaks at about $6 \mathrm{~h}$ following the initiation of feeding (Fig. 3), ambient DMSPd peaks much later, at 9 to $11 \mathrm{~h}$ after the initiation of feeding, a time when fecal elimination has already declined dramatically. One might wonder if the nonsettling floc we observed in our fecal collections, starting at $6 \mathrm{~h}$ following the initiation of feeding, might account for the rise in DMSPd. The evidence we have would suggest that it does not, because there is no way to account for a delay of several hours between the fecal elimination of the floc and the effect on DMSPd. The floc, being a product of the fish, would have been eliminated at roughly the height of the mid-water sampling tube from which we drew water samples for measurement of DMSPd. Moreover, within the confines of our tanks, swimming by our schools of menhaden generated quite a bit of turbulence and stirred the water, just as Durbin \& Durbin (1981) observed. These observations strongly suggest that if the floc were the source of the ambient DMSPd, the time courses of defecation and DMSPd concentration would match.

In considering the rise in ambient DMSPd, it is germane to recall (Durbin \& Durbin 1981) that in menhaden the excretion of dietary nitrogen as ammonium rises rapidly within just 1 to $2 \mathrm{~h}$ after the initiation of feeding, and the elimination of nitrogen destined for excretion lags behind the ingestion of the nitrogen by only 1 to $2 \mathrm{~h}$. These results point to rapid digestion, assimilation, and catabolism of ingested proteins and other nitrogenous compounds. Why a substantial portion of ingested DMSP is not processed and eliminated in dissolved form with similar rapidity is a puzzle.

Our data on tissue deposition reveal that DMSP concentrations in menhaden tissues are highly responsive to diet. Prior studies of muscle DMSP in wild-caught fish of a number of species (not including menhaden) have found that concentrations are usually $<20 \mathrm{nmol}$ $\mathrm{g}^{-1}$, and concentrations of $\geq 100 \mathrm{nmol} \mathrm{g}^{-1}$ are commercially problematic, because the DMS liberated during some types of processing can impart unsatisfactory tastes and odors (Motohiro 1962, Iida et al. 1986, Dacey et al. 1994). Our data show that in menhaden a single feeding of Prorocentrum micans drives concentrations in the swimming muscles and carcass (free of the gastrointestinal tract) to far higher levels (Table 2). Iida et al. (1986) demonstrated, using artificial diets, that the muscle concentration of DMSP in carp and trout rises rapidly when DMSP is added to the diet, then declines substantially back toward background levels within a week after DMSP is removed from the diet. Our study is the first to confirm the dynamic nature of tissue DMSP accumulation in a species of fish consuming one of its native foods.

To estimate the size of the meal we provided in our study of tissue deposition, we multiplied algal cell volume by the number of cells fed. Based on the cell dimensions we measured $(37 \times 20 \mu \mathrm{m})$, we calculated

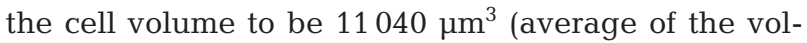
umes of oblate and prolate spheroids). Calculating from this figure and an initial cell density of 2300 cells $\mathrm{ml}^{-1}$ (Table 1), the volume of algal material fed was $13.5 \mathrm{ml}$, corresponding to $0.54 \mathrm{ml}$ for each $40 \mathrm{~g}$ fish in the school of 25. According to A. Durbin (pers. comm.) a juvenile menhaden ordinarily eats about $10 \%$ of its body weight per day. Thus, the algal meal we provided amounted to about $14 \%$ of a day's food. Clearly, menhaden feeding exclusively for days in a row on DMSP-containing phytoplankton could be expected to reach far higher tissue concentrations than those we observed.

According to Iida et al. (1986), the length of time carp require to fully dissipate muscle DMSP is $14 \mathrm{~d}$; rainbow trout require a similar length of time if their accumulation is $30 \mathrm{nmol} \mathrm{g}^{-1}$, but longer if their accumulation is higher. If menhaden are similar to these species, we can conclude that after a single meal, they accumulate about one-third of the ingested DMSP in their tissues and subsequently discharge that portion gradually into the environment over a period of $\geq 2$ wk. Tang et al. (2000) provide an enlightening discussion of the chemical forms in which tissue DMSP might be lost, concluding that in the copepod Temora longicornis tissue DMSP is lost principally as DMSPd. A point worth noting is that a relatively prompt decline of tissue DMSP following removal of DMSP from the diet is not universal among animals (Ackman et al. 1966); some mollusks exhibit no decline in tissue DMSP after many weeks on a DMSP-free diet (authors' pers. obs.).

Our observations on feces production by menhaden are, in general, commensurate with those reported by Durbin \& Durbin (1981) in a study on individuals much larger than our fish. Durbin \& Durbin, while not reporting production of a nonsettling floc with the feces, observed as we have that menhaden produce cohesive fecal pellets that tend to sink rapidly toward the bottom. They reported that production of feces started about $2.4 \mathrm{~h}$ after initiation of feeding. Although we did not sample at that time, by $3.4 \mathrm{~h}$ we observed abundant production of feces and fecal elimination of DMSP, just as they observed fecal elimination of dietary con- 
stituents at a similar time. Durbin \& Durbin calculated the digestive tract residence time for egested phytoplankton constituents to be typically 4 to $6 \mathrm{~h}$, values commensurate with the timing of fecal DMSP elimination we observed.

Our washing of feces to minimize contamination with uneaten Prorocentrum micans probably resulted in the discard of an unknown fraction of fecal DMSP prior to analysis. Although Durbin \& Durbin (1981) presented evidence that washing the feces of menhaden does not subtract content, our impression was that the nonsettling floc that we discarded by washing was fecal. We tend to believe, therefore, that our estimate of $10 \%$ of ingested DMSP being excreted in the feces is an underestimate of the total. Our measures of fecal DMSP represent the DMSP voided in discrete fecal pellets that tend to sink to the bottom; the washing procedure had the advantage of ensuring accurate measurement of this part of the DMSP. The fact that the fecal DMSP we measured at $1.2 \mathrm{~h}$ after feeding (Fig. 3) was low, even though most of the algal meal had yet to be cleared from the water at that time, demonstrates that our fecal washing procedure prevented our fecal DMSP measurements from being distorted by contamination with uneaten algal cells.

Prior information on DMSP in fish feces is sketchy (Ackman et al. 1966, Dacey et al. 1994). There is, however, a growing literature on DMSP in copepod and euphausid feces, emphasizing that the incorporation of DMSP into feces can greatly affect its dynamic fate by tending to send the DMSP to the bottom, facilitate its release to the water column, or enhance its accessibility to microbial metabolism (Daly \& DiTullio 1996, Kwint et al. 1996, Tang 2001, Yoch 2002). Some of the copepod literature suggests that DMSP within fecal pellets is poised to be lost relatively rapidly into the water column (Tang 2001), and therefore DMSP within the discrete fecal pellets of menhaden might be the source for the rise in ambient DMSPd we observed (Fig. 2). Investigation will be required to assess this hypothesis. A reason to discount the hypothesis at present is the quantitative mismatch that, whereas only $10 \%$ of ingested DMSP is incorporated into fecal pellets, $21 \%$ shows up as DMSPd; one would think that if the fecal pellets were the source of the DMSPd, the total DMSP present as DMSPd could not exceed the DMSP in the pellets.

A noteworthy incidental observation we made was that our menhaden rejected the naked dinoflagellate Amphidinium carterae. We attempted to use cultures of A. carterae as food, because it proliferates more rapidly and dependably than Prorocentrum micans. The menhaden, however, despite exhibiting the sort of swimming associated with feeding, ingested none, as indicated by the lack of decline in DMSPp for $>10 \mathrm{~h}$. Durbin \& Durbin
(1981) also reported on a dramatic case of feeding selectivity in menhaden, which failed to feed on zooplankton samples containing crab larvae (zoeas).

Knowledge of the processing of ingested DMSP by menhaden is important because menhaden are likely to be among the principal animals that affect the fate of phytoplankton DMSP in coastal and estuarine waters within their range of distribution. Owing to the large numbers of menhaden (see 'Introduction'), schools can have substantial metabolic effects on ecosystems. Calculations indicate, for example, that healthy menhaden populations might at times process all the water in the Chesapeake Bay in a day or less (Durbin \& Durbin 1975). In Narragansett Bay, schools of menhaden sometimes significantly alter ambient water properties; they can lower the concentrations of dissolved $\mathrm{O}_{2}$ and chlorophyll $a_{\text {, }}$ and raise the concentration of ammonium (Oviatt et al. 1972). There is thus reason to believe that schools of menhaden can significantly affect DMSP and DMS dynamics on ecosystem scales.

Of the processes we measured in our study during the first $24 \mathrm{~h}$ following feeding, the quantitatively most important is deposition of DMSP in the tissues of the fish. Even the relatively small meal we provided resulted in tissue DMSP concentrations higher than those that have been observed to cause offensive tastes and odors via DMS production (Ackman et al. 1966, Levasseur et al. 1994). Menhaden are key forage items for piscivorous table fish such as bluefish, striped bass, and bonito (Ahrenholz 1991, Walter \& Austin 2003). Variations in the sensory quality of the meat of these piscivores could readily be consequences of the amounts of DMSP they accumulate via menhaden consumption.

Acknowledgements. J. Burnett, S. Hill, D. Kulis, and D. Leavitt made essential contributions. Others to whom thanks are due for invaluable assistance are M. Dennett, A. Durbin, D. Franks, K. Friedland, L. Hare, W. Hettler, B. Lancaster, J. McDowell, F. Nichy, D. Radosh, and G. Wikfors. Several anonymous reviewers offered helpful suggestions. Financial support came from Michigan State University (R.W.H. sabbatical) and National Science Foundation, Division of Ocean Sciences Grant nos. OCE-9411497 and OCE-9102532.

\section{LITERATURE CITED}

Ackman RG, Dale J, Hingley J (1966) Deposition of dimethyl$\beta$-propiothetin in Atlantic cod during feeding experiments. J Fish Res Board Can 23:487-497

Ahrenholz DW (1991) Population biology and life history of the North American menhadens, Brevoortia spp. Mar Fish Rev 53(4):3-19

Andreae MO (1990) Ocean-atmosphere interactions in the global biogeochemical sulfur cycle. Mar Chem 30:1-29

Andreae MO, Crutzen PJ (1997) Atmospheric aerosols: biogeochemical sources and role in atmospheric chemistry. Science 276:1052-1058 
Archer SD, Stelfox-Widdicombe CE, Malin G, Burkill PH (2003) Is dimethyl sulfide production related to microzooplankton herbivory in the southern North Sea? J Plankton Res 25:235-242

Bates TS, Lamb, BK, Guenther A, Dignon J, Stoiber RE (1992) Sulfur emissions to the atmosphere from natural sources. J Atmos Chem 14:315-337

Brooke RO, Mendelsohn JM, King FJ (1968) Significance of dimethyl sulfide to the odor of soft-shell clams. J Fish Res Board Can 25:2453-2460

Charlson RJ, Lovelock JE, Andreae MO, Warren SG (1987) Oceanic phytoplankton, atmospheric sulphur, cloud albedo and climate. Nature 326:655-661

Dacey JWH, Blough NV (1987) Hydroxide decomposition of dimethylsulfoniopropionate to form dimethylsulfide. Geophys Res Lett 14:1246-1249

Dacey JWH, Wakeham SG (1986) Oceanic dimethylsulfide: production during zooplankton grazing on phytoplankton. Science 233:1314-1316

Dacey JWH, King GM, Lobel PS (1994) Herbivory by reef fishes and the production of dimethylsulfide and acrylic acid. Mar Ecol Prog Ser 112:67-74

Daly KL, DiTullio GR (1996) Particulate dimethylsulfoniopropionate removal and dimethylsulfide production by zooplankton in the Southern Ocean. In: Kiene RP, Visscher PT, Keller MD, Kirst GO (eds) Biological and environmental chemistry of DMSP and related sulfonium compounds. Plenum, New York, p 223-238

Durbin AG, Durbin EG (1975) Grazing rates of the Atlantic menhaden Brevoortia tyrannus as a function of particle size and concentration. Mar Biol 33:265-277

Durbin EG, Durbin AG (1981) Assimilation efficiency and nitrogen excretion of a filter-feeding planktivore, the Atlantic menhaden, Brevoortia tyrannus (Pisces: Clupeidae). Fish Bull 79:601-616

Durbin AG, Durbin EG, Verity PG, Smayda TJ (1981) Voluntary swimming speeds and respiration rates of a filterfeeding planktivore, the Atlantic menhaden, Brevoortia tyrannus (Pisces: Clupeidae). Fish Bull 78:877-886

Friedland KD (1985) Functional morphology of the branchial basket structures associated with feeding in the Atlantic menhaden, Brevoortia tyrannus (Pisces: Clupeidae). Copeia 1985:1018-1027

Friedland KD, Haas LW, Merriner JV (1984) Filtering rates of the juvenile Atlantic menhaden Brevoortia tyrannus (Pisces: Clupeidae) with consideration of the effects of detritus and swimming speed. Mar Biol 84:109-117

Friedland KD, Ahrenholz DW, Guthrie JF (1989) Influence of plankton on distribution patterns of the filter-feeder Brevoortia tyrannus (Pisces: Clupeidae). Mar Ecol Prog Ser 54:1-11

Hettler WF (1976) Influence of temperature and salinity on routine metabolic rate and growth of young Atlantic menhaden. J Fish Biol 8:55-65

Hill RW, White BA, Cottrell MT, Dacey JWH (1998) Virusmediated total release of dimethylsulfoniopropionate from marine phytoplankton: a potential climate process. Aquat Microb Ecol 14:1-6

lida H, Nakazoe J, Saito H, Tokunaga T (1986) Effect of diet on dimethyl- $\beta$-propiothetin content in fish. Bull Jpn Soc Sci Fish 52:2155-2161

June FC, Carlson FT (1971) Food of young Atlantic menhaden, Brevoortia tyrannus, in relation to metamorphosis. Fish Bull 68:493-512
Kasamatsu N, Kawaguchi S, Watanabe S, Odate T, Fukuchi M (2004) Possible impacts of zooplankton grazing on dimethylsulfide production in the Antarctic Ocean. Can J Fish Aquat Sci 61:736-743

Keller MD, Bellows WK, Guillard RRL (1989) Dimethyl sulfide production in marine phytoplankton. In: Saltzman ES, Cooper WJ (eds) Biogenic sulfur in the environment. American Chemical Society, Washington, DC, p 167-182

Kwint RLJ, Irigoien X, Kramer KJM (1996) Copepods and DMSP. In: Kiene RP, Visscher PT, Keller MD, Kirst GO (eds) Biological and environmental chemistry of DMSP and related sulfonium compounds. Plenum, New York, p 239-252

Lee PA, Saunders PA, de Mora SJ, Deibel D, Levasseur M (2003) Influence of copepod grazing on concentrations of dissolved dimethylsulfoxide and related sulfur compounds in the North Water, northern Baffin Bay. Mar Ecol Prog Ser 255:235-248

Levasseur M, Keller MD, Bonneau E, D'Amours D, Bellows WK (1994) Oceanographic basis of a DMS-related Atlantic cod (Gadus morhua) fishery problem: blackberry feed. Can J Fish Aquat Sci 51:881-889

Malin G, Kirst GO (1997) Algal production of dimethyl sulfide and its atmospheric role. J Phycol 33:889-896

McHugh JL, Oglesby RT, Pacheco AL (1959) Length, weight, and age composition of the menhaden catch in Virginia waters. Limnol Oceanogr 4:145-162

Motohiro T (1962) Studies on the petroleum odour in canned chum salmon. Mem Fac Fish Hokkaido Univ 10:1-65

Nicholson WR, Higham JR Jr (1965) Age and size composition of the menhaden catch along the Atlantic coast of the United States, 1962, with a brief review of the commercial fishery. Special Scientific Report, Fisheries No. 527, U.S. Fish \& Wildlife Service, Washington, DC

Oviatt CA, Gall AL, Nixon SW (1972) Environmental effects of Atlantic menhaden on surrounding waters. Chesapeake Sci 13:321-323

Smith JW (1991) The Atlantic and Gulf menhaden purse seine fisheries: origins, harvesting technologies, biostatistical monitoring, recent trends in fisheries statistics, and forecasting. Mar Fish Rev 53(4):28-41

Tang KW (2001) Defecation of dimethylsulfoniopropionate (DMSP) by the copepod Acartia tonsa as functions of ambient food concentration and body DMSP content. J Plankton Res 23:549-553

Tang KW, Fenn TD, Visscher PT, Dam HG (2000) Regulation of body dimethylsulfoniopropionate (DMSP) content by the copepod Temora longicornis: a test of four mechanisms. Mar Biol 136:749-757

Vaughan DS (1991) Preface. Menhaden: the resource, the industry, and a management history. Mar Fish Rev 53(4): $1-2$

Vaughan DS, Merriner JV (1991) Assessment and management of Atlantic and Gulf menhaden stocks. Mar Fish Rev 53(4):49-57

Walter JF, Austin HM (2003) Diet composition of large striped bass (Morone saxatilis) in Chesapeake Bay. Fish Bull 101: $414-423$

Yoch D (2002) Dimethylsulfoniopropionate: its sources, role in the marine food web, and biological degradation to dimethylsulfide. Appl Environ Microbiol 68:5804-5815 